\title{
Pembuatan Surfaktan Berbahan Dasar Jerami Padi
}

\author{
Sri Wahyu Murni, Sri Wahyuni Santi R, IGS Budiaman, Ika Perwitasari dan \\ Abdul Aji Kresna Tri Anggara \\ Program Studi Teknik Kimia, FTI, UPN "Veteran" Yogyakarta \\ Jl SWK 104 (Lingkar Utara) Condong Catur Yogyakarta-55283 \\ E-mail: wahyuswm@yahoo.com
}

\begin{abstract}
Indonesia's oil production has declined due to the low level of production of oil wells that have been old. Extraction of oil from the wells can be enhanced by the injection of surfactant. Potential raw material for the manufacture of surfactants, especially the waste material so that lower-priced. This material include lignocellulosic materials and plantation agricultural waste. Rice straw is one of them. This study aims to make surfactants from rice straw. The axpetriment was conducted through the steps of: (1) preparation of raw materials, (2) delignification and isolation of lignin, (3) sulfonation of lignin using $\mathrm{NaHSO}_{3}$. Delignification of rice straw held at a temperature of $166^{\circ} \mathrm{C}$ and a pressure of $1.2 \mathrm{~atm}$. Sulfonated of lignin conducted at a temperature of $90-95^{\circ} \mathrm{C}$ and $\mathrm{pH} 7$. Lignin and sodium lignosulfonate tested using FTIR and gravimetric. The results show at $2.5 \mathrm{~g}$ lignin, weight percent of $\mathrm{NaHSO}_{3} 60 \%$ of the weight of lignin, $\mathrm{pH} 7$, temperature $90-95^{\circ} \mathrm{C}$ for 4 hour reaction obtained 2,5509 $\mathrm{g}$ of sodium lignosulfonate (SLS). Sodium lignosulfonate is soluble in water. Sodium lignosulfonate phase behavior test using crude oil from Oil Drilling Tanjung, South Kalimantan, at the surfactant concentration 3000 and 5000 ppm result that the type of emulsion is water in oil. So that this surfactant not suggested for EOR.
\end{abstract}

Kata kunci: lignosulfonate, surfactant, rice straw, emulsion, lignin.

\section{I.Pendahuluan.}

Produksi minyak bumi Indonesia semakin menurun karena sumur-sumur minyak telah tua sehingga tingkat produksi juga menurun. Pemungutan minyak dari sumur bisa ditingkatkan dengan melakukan jalan injeksi surfaktan. Bahan baku baru yang potensial untuk pembuatan surfaktan, terutama bahan buangan yang berharga murah. Salah satu bahan yang potensial untuk pembuatan surfaktan adalah jerami padi. Berdasarkan data dari Badan Pusat Statistik (2011), produksi padi Indonesia sebesar 67,31 juta ton gabah kering giling. Setiap $1 \mathrm{~kg}$ padi dihasilkan 1-1,5 kg jerami padi. Jerami padi kebanyakan dimanfaatkan sebagai campuran pakan ternak dan juga sebagai pengganti hara tanah paska panen. Pemanfaatan lainnya hanya sebagian kecil saja, kebanyakan sebagai bahan campuran gerabah dan bahan bakar pembuatan genting.Pemanfaatan tersebut dirasakan kurang optimal jika dibandingkan dengan jumlah jerami yang dihasilkan. Sehingga pemanfaatan jerami padi sebagai bahan baku pembuatan surfaktan mempunyai prospek yang baik. Dengan demikian manfaat jerami padi dapat ditingkatkan nilai ekonominya. Tujuan penelitian ini adalah untuk memanfaatkan lignin hasil isolasi dari jerami padi sebagai surfaktan sodium lignosulfonat.

\subsection{Surfaktan.}

Surfaktan (surface active agent) merupakan molekul yang memiliki gugus polar yang suka air (hidrofilik) dan gugus non polar yang suka minyak (lipofilik) sekaligus, sehingga dapat mempersatukan campuran yang terdiri dari minyak dan air. Surfaktan adalah bahan aktif permukaan, yang bekerja menurunkan tegangan permukaan cairan, sifat aktif ini diperoleh dari sifat ganda molekulnya. Bagian polar molekulnya dapat bermuatan positif, negatif ataupun netral, bagian polar mempunyai gugus hidroksil sementara bagian non polar biasanya merupakan rantai alkil yang panjang. Surfaktan pada umumnya disintesis dari turunan minyak bumi namun limbahnya dapat mencemari lingkungan, karena sifatnya yang sukar terdegradasi, selain itu minyak bumi merupakan sumber bahan baku yang tidak dapat diperbarui.

Surfaktan banyak ditemui di bahan deterjen, kosmetik, farmasi dan tekstil. Produk pangan seperti es krim juga menggunakan surfaktan sebagai bahannya. Karena sifatnya yang menurunkan tegangan permukaan, surfaktan dapat digunakan sebagai bahan pembasah (wetting agent), bahan pengemulsi (emulsion agent) dan sebagai bahan pelarut (solubilizing agent). (Supriadi Sadi, 1993)

\subsection{Lignin}

Bahan lignoselulosa merupakan bahan yang potensial sebagai bahan baku surfaktan. Salah satunya adalah jerami padi, bahan tersebut mempunyai potensi untuk digunakan sebagai bahan baku pembuatan surfaktan lignosulfonat, dikarenakan jerami padi mempunyai kandungan lignin yang cukup besar, yaitu 12-16\%. Surfaktan lignosulfonat adalah surfaktan yang berbasis lignin dalam pembuatannya. Ditinjau dari komposisi kimianya, bahan lignoselulosa mempunyai kandungan utama berupa 3 (tiga) macam polimer yang berbeda, yang dikenal dengan lignin, hemiselulosa, dan selulosa, yang saling berikatan membentuk satu kesatuan yang utuh. Besarnya kandungan masing-masing komponen bergantung pada jenis biomassa, umur, dan kondisi lingkungan tempat biomassa tersebut tumbuh dan berkembang. (Bailey \& Ollis , 1986) 


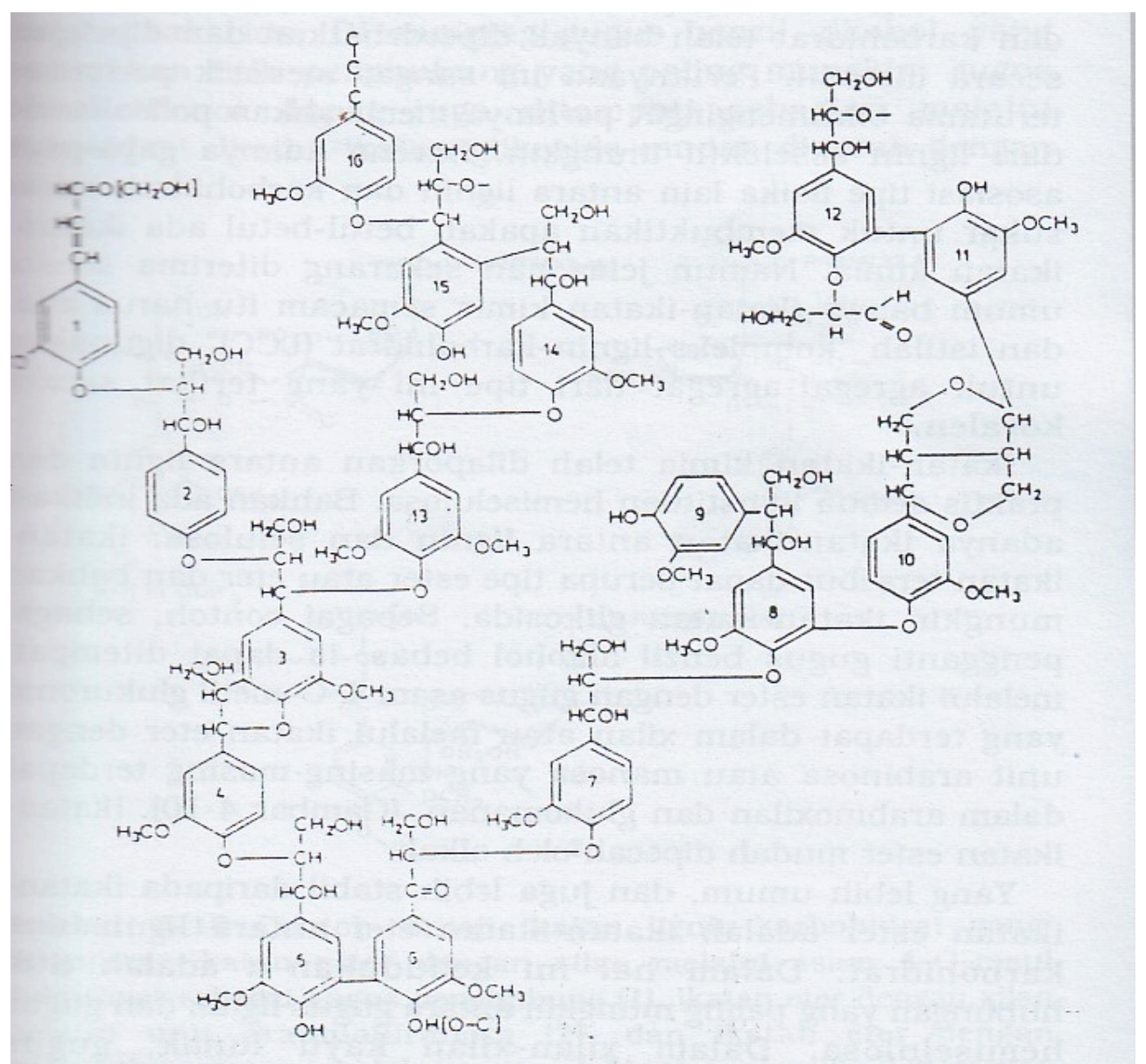

Gambar 1. Struktur Lignin (Sjostrom, 1995)

Lignin merupakan senyawa polimer yang terdapat pada dinding sel tanaman berkayu. Adanya lignin dan Wegener, 1995). Struktur lignin dalam (Sjostrom, menyebabkan dinding sel tanaman menjadi keras. (Fengel 1995) disajikan pada Gambar 1.

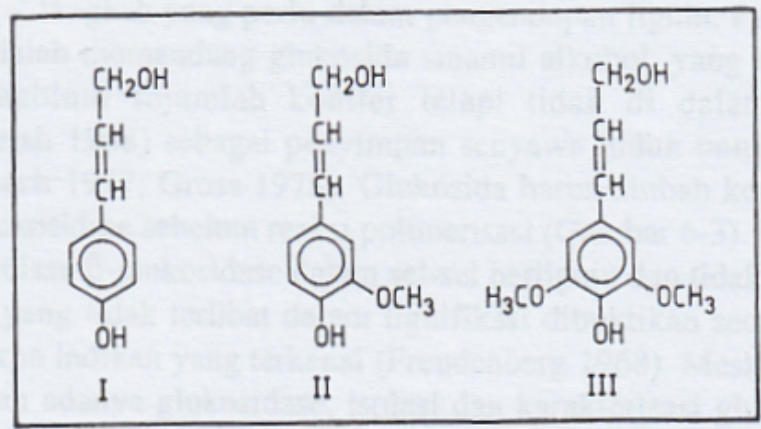

Gambar 2. Struktur monomer lignin I. p-kumaril alkohol (unit p-hidroksifenil), II. koniferil alkohol (unit guaiasil), III. sinapsil alkohol (unit siringil) (Fengel dan Wegner, 1995)

Makromolekul lignin tersebut, terbentuk dari tiga macam monomer yaitu: p-kumaril alkohol (unit p-hidroksifenil), II. koniferil alkohol (unit guaiasil), III. sinapsil alkohol (unit siringil). Struktur masing-masing unit disajikan pada Gambar 2. (Fengel dan Wegener, 1995)

\subsection{Pembentukan Lignosulfonat.}

Pembentukan surfaktan (lignosulfonat) terjadi melalui reaksi sulfonasi molekul lignin dengan bisulfit. (Dilling, 1986) Sulfonasi merupakan reaksi antara ion bisulfit dengan molekul lignin. Gugus sulfonat pada lignosulfonat merupakan gugus hydrophilic sehingga menyebabkan lignosulfonat mempunyai struktur amphipatic (surfaktan). Reaksi yang terjadi pada proses sulfonasi lignin ini termasuk reaksi ireversibel dan bersifat endotermis. Suhu dan $\mathrm{pH}$ merupakan faktor yang paling berpengaruh pada reaksi pembentukan lignosulfonat ini. 


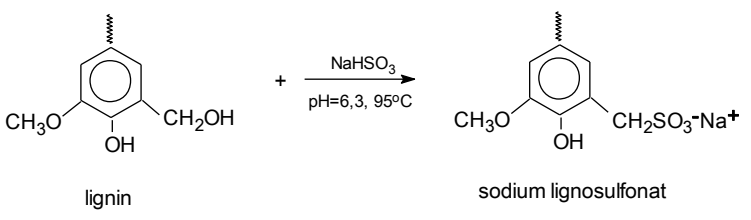

Gambar 3. Reaksi Sulfonasi Lignin (Dilling, 1986)

Lignosulfonat merupakan surfaktan yang banyak digunakan di industri. Penggunaan lignosulfonat sangat beragam, yaitu sebagai penstabil dalam industri pengeboran minyak, pelarut dalam industri tekstil, emulsifier dalam pembuatan pelumas, bahan perekat dan bahan pendispersi untuk papan gipsum, bahan aditif untuk media kultur, sebagai plastiziser pada adonan beton, sebagai water reducing admixture dan juga sebagai retarder. Surfaktan lignosulfonat yang dihasilkan dari jerami padi merupakan jenis sodium lignosulfonat karena

Penelitian ini dilakukan melalui tiga tahapan, yaitu tahap persiapan bahan, delignifikasi dan isolasi lignin dan tahap sintesa senyawa lignosulfonat. Tahap persiapan bahan terdiri dari persiapan jerami padi, pembuatan serpihan jerami padi bebas zat ekstraktif. Tahap kedua adalah delignifikasi serpihan jerami padi, isolasi lignin dari lindi hitam jerami padi dan karakterisasi isolat lignin. Pada tahap sintesa senyawa lignosulfonat dilakukan dengan mengkaji pengaruh faktor konsentrasi sodium bisulfit $\left(\mathrm{NaHSO}_{3}\right)$ dan waktu reaksi pada proses sulfonasi lignin, menghitung rendemen, dan analisis gugus fungsi 2.2.Alat.

Peralatan utama yang digunakan dalam penelitian ini adalah panci bertekanan untuk proses delignifikasi,

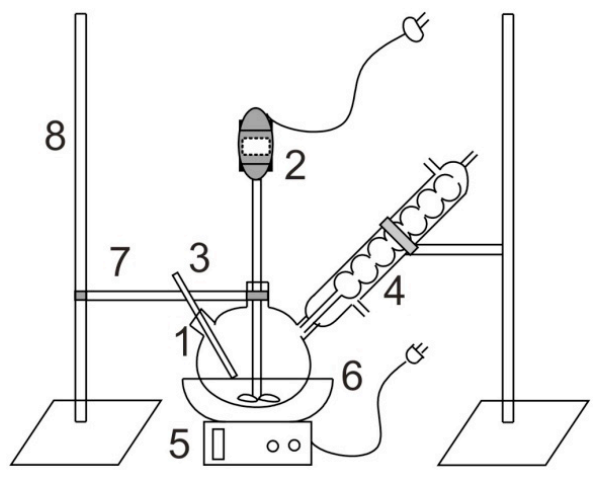

menggunakan sodium bisulfit $\left(\mathrm{NaHSO}_{3}\right)$ sebagai agen pensulfonasinya.

\subsection{Uji Kinerja Surfaktan}

Uji kinerja surfaktan pada penelitian ini terbatas pada phase behavior. Uji phase behavior di laboratorium dilakukan terhadap fluida campuran surfaktan, air dan minyak dengan cara uji tabung, yaitu dengan mencampurkan fluida dengan volume dan konsentrasi tertentu. Campuran kemudian dikocok dan dipanaskan dalam oven hingga suhu $\pm 60^{\circ} \mathrm{C}$ (mendekati suhu reservoir). Penentuan phase behavior sangat penting dalam memperkirakan kinerja peningkatan perolehan minyak dengan metode injeksi surfaktan. (Berger, 2009)

\section{II.Metodologi.}

dengan spektrofotometer FTIR serta uji daya dispersi surfaktan pada minyak mentah (crude oil).

\subsection{Bahan.}

Bahan yang digunakan dalam penelitian meliputi: (1) bahan baku Jerami padi diperoleh dari Dusun Dewan, Pedukuhan corongan, Desa Maguwoharjo, Kecamatan Depok, Kabupaten Sleman, Propinsi DIY, (2) bahanbahan kimia: $\mathrm{NaHSO}_{3}$, aquades, $\mathrm{H}_{2} \mathrm{SO}_{4}$, toluena, etanol $95 \%$, aseton, $\mathrm{NaOH}$, metanol, natrium/sodium lignosulfonat (SLS) komersial.

Gambar 4. Rangkaian alat sulfonasi.

rangkaian alat sulfonasi yang berupa labu leher tiga yang dilengkapi pemanas dan pengaduk (Gambar 4), alat ekstraksi soxhlet, rangkaian alat distilasi, oven, sentrifugasi, corong pemisah, rangkaian alat titrasi, Spektrometer-FTIR

\subsection{Cara Kerja.}

\subsubsection{Tahap Persiapan Bahan.}

Jerami padi dibersihkan dan dikeringkan di udara terbuka (sinar matahari). Jerami padi yang telah kering dipotong dengan ukuran panjang $\pm 0,5 \mathrm{~cm}$. Jerami padi diblender sehingga menjadi serpihan.

\subsubsection{Pembuatan serbuk Jerami padi bebas bahan ekstraktif}

Serpihan jerami padi yang telah dikeringkan diekstraksi berturut-turut dengan menggunakan toluen dan etanol dengan perbandingan 1:2 (v/v) selama 2 jam pada alat soxhlet. Setelah itu, serbuk jerami padi tersebut di ekstraksi kembali menggunakan etanol teknis 96\% selama 2 jam pada alat soxhlet. Residu dikeringkan dengan oven dan hasil pengeringan tersebut diekstraksi kembali dengan menggunakan air pada suhu $100^{\circ} \mathrm{C}$ selama 1 jam sehingga didapatkan serpihan jerami padi yang bebas zat ekstraktif. 


\subsubsection{Delignifikasi Jerami Padi .}

Serbuk jerami padi yang bebas zat ekstraktif dilakukan pemasakan di dalam alat panci bertekanan untuk mendapatkan lindi hitam (black liquor) jerami padi. Serpihan jerami padi, larutan pemasak dan bahan kimia ditetapkan dengan komposisi tertentu dimasukkan ke dalam alat panci bertekanan. Pemasakan ini dilakukan dua tahap, yaitu pemasakan dari suhu kamar sampai suhu maksimum dan pemasakan yang dipertahankan pada suhu maksimum selama waktu tertentu. Kondisi delignifikasi serpihan jerami padi adalah: a). Berat kering serpihan (BKS) jerami padi: 25 gram, b). Larutan pemasak : 10: 1(v/b) terhadap BKS $(250 \mathrm{ml}$ larutan pemasak: $25 \mathrm{~g}$ jerami), c). Komposisi larutan pemasak : etanol teknis 95\% : air ( $1: 1)$, d). Katalis $(\mathrm{NaOH}): 10 \%$ terhadap BKS, e). Suhu maksimum : $\left.116^{\circ} \mathrm{C}, \mathrm{f}\right)$. Tekanan: 1,15 atm, g). Waktu pemanasan awal sampai suhu maksimum : 1,5 jam dan h). Waktu pada suhu maksimum : 3 jam

Hasil delignifikasi terdiri atas dua bagian yaitu lindi hitam dan serpihan (pulp) yang agak lunak. Serpihan yang dihasilkan dicuci dengan aseton teknis, kemudian dengan air dan sisa cairan pencucian ditambahkan pada lindi hitam tersebut. Lindi hitam disaring dengan menggunakan kain nylon untuk memisahkan bahan terlarut dalam lindi hitam (filtrat) dan tidak terlarut (residu).

\subsubsection{Isolasi lignin dari lindi hitam Jerami Padi.}

Lindi hitam yang telah disaring (filtrat) diendapkan ligninnya dengan cara titrasi oleh asam $\left(\mathrm{H}_{2} \mathrm{~S}_{4}\right)$ dengan konsentrasi 20\% (persen $\mathrm{v} / \mathrm{v}$ ). Titrasi dilakukan secara perlahan-lahan $1 \mathrm{ml}$ per menit sampai $\mathrm{pH} \mathrm{2,} \mathrm{kemudian}$ didiamkan minimal selama 8 jam agar pengendapan sempurna. Endapan lignin dipisahkan dari lindi hitam yang telah diasamkan dengan menggunakan alat sentrifuse (3500 rpm, 20 menit). Untuk meningkatkan kemumian lignin, endapan lignin tersebut dilarutkan kembali kedalam larutan alkali yaitu $\mathrm{NaOH} 1 \mathrm{~N}$, kemudian larutan lignin diendapkan kembali dengan cara titrasi menggunakan asam $\left(\mathrm{H}_{2} \mathrm{~S}_{4}\right)$ seperti proses pengendapan pertama. Endapan lignin dipisahkan kembali dari larutannya dengan menggunakan alat sentrifuse, kemudian disaring dengan kertas saring Whatman No. 42 sehingga dihasilkan larutan lignin dengan kemurnian yang lebih tinggi. Selanjutnya endapan dicuci menggunakan $\mathrm{H}_{2} \mathrm{~S}_{4} 0,01 \mathrm{~N}$, dilanjutkan pencucian dengan aquades dan disaring menggunakan penyaring vakum. Endapan yang telah dicuci dikeringkan dalam oven $\left(50-60^{\circ} \mathrm{C}\right)$ selama 24 jam sehingga dihasilkan lignin berbentuk tepung.

\section{Sulfonasi lignin}

Lignin dengan berat tertentu (2, 5 gram) disuspensikan dengan $75 \mathrm{ml}$ air atau perbandingan lignin:air (1:30 w/w), dalam labu bulat leher 3 ukuran $250 \mathrm{ml}$ dan diaduk menggunakan magnetic stirrer. Suspensi ini ditambahkan sodium bisulfit pada persentase berat $60 \%$ terhadap berat lignin, dan diatur $\mathrm{pH}$ menggunakan larutan $\mathrm{NaOH}$ sampai $\mathrm{pH}$ 7, yang ditunjukkan dalam skala indikator $\mathrm{pH}$ universal. Campuran tadi diaduk dengan pengaduk magnetik stirrer dan dikondisikan pada suhu reaksi 90$95^{\circ} \mathrm{C}$. Proses ini dilakukan dengan pemanasan selama waktu tertentu yang dimonitor dengan termometer.

\subsubsection{Prosedur pemurnian hasil sulfonasi (Ani Suryani dkk, 2010)}

Hasil reaksi berupa produk lignosulfonat, sisa reaksi (lignin dan sodium bisulfit) serta air. Proses pemisahan produk lignosulfonat dan pemurnian hasil dilakukan melalui beberapa tahap, yaitu:

a. Hasil didestilasi untuk menguapkan air pada suhu $100^{\circ} \mathrm{C}$ guna mengurangi volume.

b. Larutan yang telah pekat disaring menggunakan corong buchner, kemudian didapatkan filtrat berupa sodium lignosulfonat yang masih mengandung lignin dan sodium bisulfit (sisa reaksi)

c. Filtrat kemudian ditambahkan metanol sambil dikocok kuat sehingga bisulfit terendapkan dan disaring menggunakan corong buchner

d. Filtrat sodium lignosulfonat dan sisa lignin diuapkan untuk memekatkan sodium lignosuIfonat

e. Sodium lignosulfonat pekat yang diperoleh dikeringkan dalam oven suhu $60^{\circ} \mathrm{C}$, kemudian ditimbang sampai diperoleh berat konstan. Setelah itu, ditentukan persen berat rendemennya, diamati gugus fungsinya dengan spektrometri FTIR dan an uji dispersimenggunakan mintak mentah (crude oil).

\subsubsection{Analisis hasil.}

Isolat lignin dan sodium lignosulfonat dikaraterisasi gugus fungsionalnya dengan spektrofotometer FTIR, serta uji kelarutan dan pengamatan warna secara visual. Sodium lignosulfonat juga diuji sifat dispersi menggunakan minyak mentah.

\section{Uji phase behavior SLS hasil sintesis}

Uji phase behavior dilakukan dengan cara mencampurkan minyak mentah (crude oil) dengan larutan surfaktan pada konsentrasi $(3000,5000)$ ppm dengan perbandingan volume minyak:larutan surfaktan 1:1 (v/v) ke dalam gelas ukur. Campuran dikocok hingga bercampur dan dimasukkan ke dalam oven pada suhu $60^{\circ} \mathrm{C}$. Jenis emulsi yang terbentuk diamati.

\section{III.Hasil dan Pembahasan}

\section{Pretreatment Bahan Baku dan Penghilangan Ekstraktif}

Jerami padi dikeringkan dan selanjutnya dihancurkan sehingga diperoleh serpihan. Jerami padi yang telah dihaluskan diuji kandungan hemiselulosa, selulosa, dan lignin. Hasilnya diperoleh berturut-turut: 45,5\%, 37,8\% dan $4,65 \%$. Pada tahapan penghilangan ekstraktif, jerami padi berturut tutut diekstraksi menggunakan larutan toluena-etanol $(1: 2 \mathrm{v} / \mathrm{v})$, etanol 95\% dan air. Tujuan dari proses ini adalah untuk menghilangkan bahan-bahan yang dapat larut dalam pelarut organik dan air. Bahan-bahan ini meliputi terpenoid, fenol, lemak dan lain-lain. (Fengel dan Wegener, 1985)

\subsection{Isolasi Lignin dari Jerami Padi.}

Setelah pemasakan 3 jam diperoleh larutan berwarna coklat kehitaman. Lindi hitam selanjutnya diasamkan menggunakan $\mathrm{H}_{2} \mathrm{SO}_{4} 5 \%$ sampai $\mathrm{pH} 2$ dan disentrifugasi 3000 rpm untuk mengendapkan padatan lignin. Lignin 
yang diperoleh selanjutnya dinetralkan dan dikeringkan pada suhu $60^{\circ} \mathrm{C}$. Lignin hasil isolasi yang diperoleh berupa tepung berwarna coklat dan tidak larut dalam air.. Sebanyak 4,52 gram lignin diperoleh dari 100 gram jerami padi bebas ekstraktif. $(4,52 \%)$
Pada Gambar 5 dan Tabel 1, identifikasi gugus fungsional lignin menunjukkan pita serapan lebar pada bilangan gelombang $3425,58 \mathrm{~cm}^{-1}$ merupakan rentangan gugus OH. Pada bilangan gelombang 2939,52 $\mathrm{cm}^{-1}$ merupakan rentangan $\mathrm{OH}$ pada gugus metil dan metilena. (Fengel dan Wegener, 1995)

Tabel 1. Identifikasi Gugus Fungsi Lignin Hasil isolasi Jerami padi

\begin{tabular}{cl}
\hline $\begin{array}{c}\text { Bilangan gelombang lignin hasil } \\
\text { isolasi }\left(\mathbf{c m}^{-1}\right)\end{array}$ & Gugus fungsi \\
\hline 3425,58 & rentangan $-\mathrm{OH}$ \\
2931,52 & rentangan $\mathrm{C}-\mathrm{H}$ pada gugus metil dan metilena \\
1597,06 & Vibrasi cincin aromatik \\
1504,48 & Vibrasi cincin aromatik \\
1458,18 & Deformasi C-H asimetri \\
1419,61 & Vibrasi cincin aromatic \\
1327,03 & vibrasi cincin siringil \\
1226,73 & vibrasi cincin guaiasil \\
1126,43 & Rentangan eter \\
1033,85 & Deformasi C-H, C-O \\
\hline
\end{tabular}

Pita serapan pada 1597,06 dan $1504,48 \mathrm{~cm}^{-1}$ menunjukkan karakteristik vibrasi cincin aromatik. Serapan pada $1458,18 \mathrm{~cm}^{-1}$ merupakan deformasi C-H asimetri dan 1419,61 $\mathrm{cm}^{-1}$ merupakan vibrasi cincin aromatik. Pita serapan 1327,03 $\mathrm{cm}^{-1}$ merupakan karakteristik vibrasi cincin siringil, sedangkan 1226,73 menunjukkan vibrasi cincin guaiasil. Pita serapan pada 1033,85 karakteristik deformasi C-H dan C-O. Adanya sedikit pergeseran bilangan gelombang bila dibandingkan dengan Fengel dan Wegener (1995), disebabkan oleh perbedaan metode isolasi lignin dan metode uji FTIR.

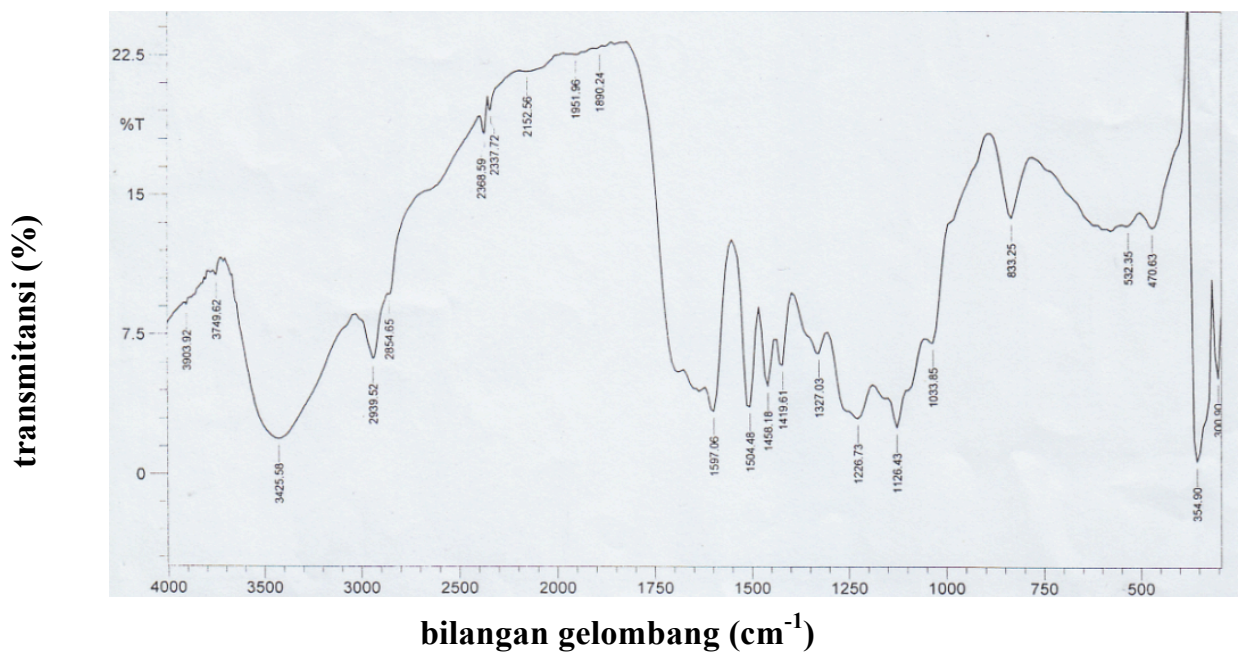

Gambar 5. Spektra FTIR Lignin Hasil Isolasi

\subsection{Sulfonasi Lignin Hasil Isolasi.}

Lignosulfonat yang dihasilkan berupa tepung warna coklat dan larut dalam air. Sulfonasi merubah sifat lignin yang tidak larut dalam air menjadi senyawa yang larut dalam air, karena masuknya gugus sulfonat yang bersifat hidrofilik. Hasil sulfonasi disajikan pada Tabel 2, terlihat bahwa pada waktu sulfonasi 4 jam diperoleh hasil lignosulfonat terbanyak.

Tabel 2. Hasil Sulfonasi Lignin

\begin{tabular}{ccc}
\hline $\begin{array}{c}\text { Waktu } \\
\text { (jam) }\end{array}$ & $\begin{array}{c}\text { Persentase berat } \mathrm{NaHSO}_{3} \\
\text { terhadap lignin } \\
(\%)\end{array}$ & $\begin{array}{c}\text { Berat SLS } \\
(\text { gram })\end{array}$ \\
\hline 1 & 60 & 0,4841 \\
4 & 60 & 2,5509 \\
\hline
\end{tabular}


Identifikasi spektra FTIR SLS bertujuan mengetahui terjadinya reaksi sulfonasi lignin menjadi sodium lignosulfonat. Identifikasi gugus fungsional SLS hasil sintesis menunjukkan pita serapan $3448,72 \mathrm{~cm}^{-1}$ merupakan rentangan $\mathrm{OH}$, pita serapan 2939,52 merupakan rentangan $\mathrm{CH}$ gugus metil dan metilena. Pita serapan 1597,06 adalah vibrasi aromatik. (Gambar 6).

TabeI 3. Identifikasi gugus fungsi SLS hasil sintesis dan SLS komersial

\begin{tabular}{ccl}
\hline $\begin{array}{c}\text { bilangan gelombang SLS } \\
\text { komersial }\left(\mathrm{cm}^{-1}\right)\end{array}$ & $\begin{array}{c}\text { bilangan gelombang SLS } \\
\text { hasil sintesis }\left(\mathrm{cm}^{-1}\right)\end{array}$ & \multicolumn{1}{c}{ gugus fungsi } \\
\hline 3425,58 & 3448,72 & rentangan OH \\
2931,80 & 2939,52 & rentangan C-H gugus metil \\
1597,06 & 1597,06 & vibrasi cincin aromatik \\
& 1512,19 & Vibrasi cincin aromatik \\
& 1458,18 & Rentangan C-H gugus metil \\
1419,61 & 1419,61 & Rentangan C-O \\
& 1327,03 & vibrasi cincin siringil (sisa reaktan) \\
& 1188,15 & vibrasi cincin guaiasil (sisa reaksi) \\
1126,43 & 1118,71 & vibrasi gugus sulfonat \\
972,12 & 964,18 & bending S-O \\
763,81 & 825,53 & vibrasi aromatik \\
624,54 & 624,94 & rentangan C-S \\
\hline
\end{tabular}

Terdapat perubahan serapan yang signifikan pada SLS yaitu serapan pada $1118,15 \mathrm{~cm}^{-1}$ adalah karakteristik vibrasi gugus sulfonat $\left(\mathrm{SO}^{-}\right)$. Rentangan $\mathrm{S}=\mathrm{O}$ pada 1041,56. Pita serapan 964,41 adalah bending S-O, pada $825,53 \mathrm{~cm}^{-1}$ merupakan vibrasi aromatik dan pita serapan 624,54 adalah karakteristik ikatan C-S. Spektrum lignin tidak menunjukkan serapan pada panjang gelombang tersebut. Tabel 2, menyajikan data serapan SLS hasil sintesis dan SLS komersial. Sedikit perbedaan pita serapan dimungkinkan oleh perbedaan metode pemurnian SLS maupun sumber lignin yang berbeda. (Gambar 6 dan 7)

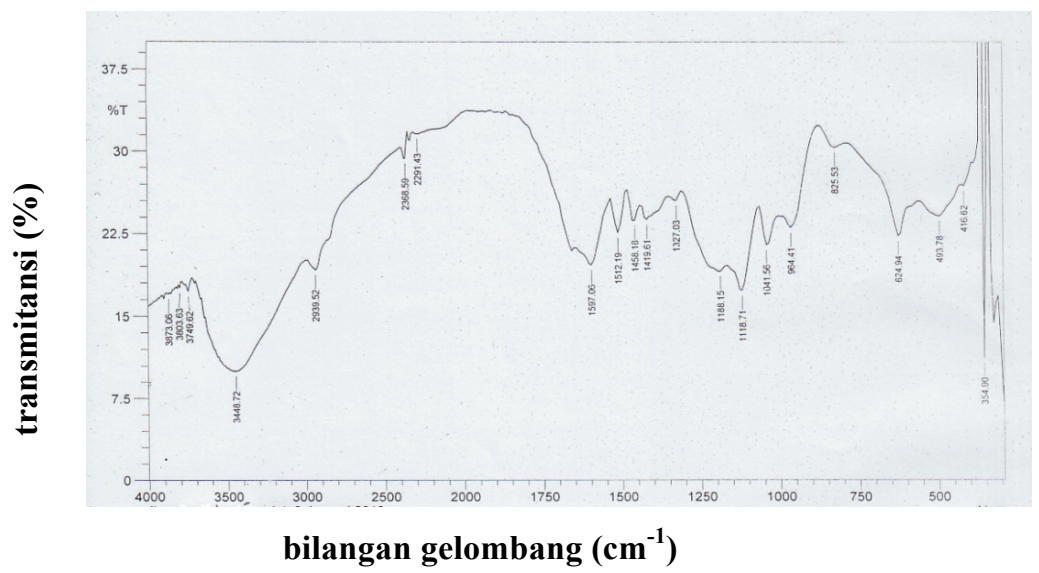

Gambar 6. Spektra FTIR Sodium Lignosulfonat (SLS) Hasil Sintesis.

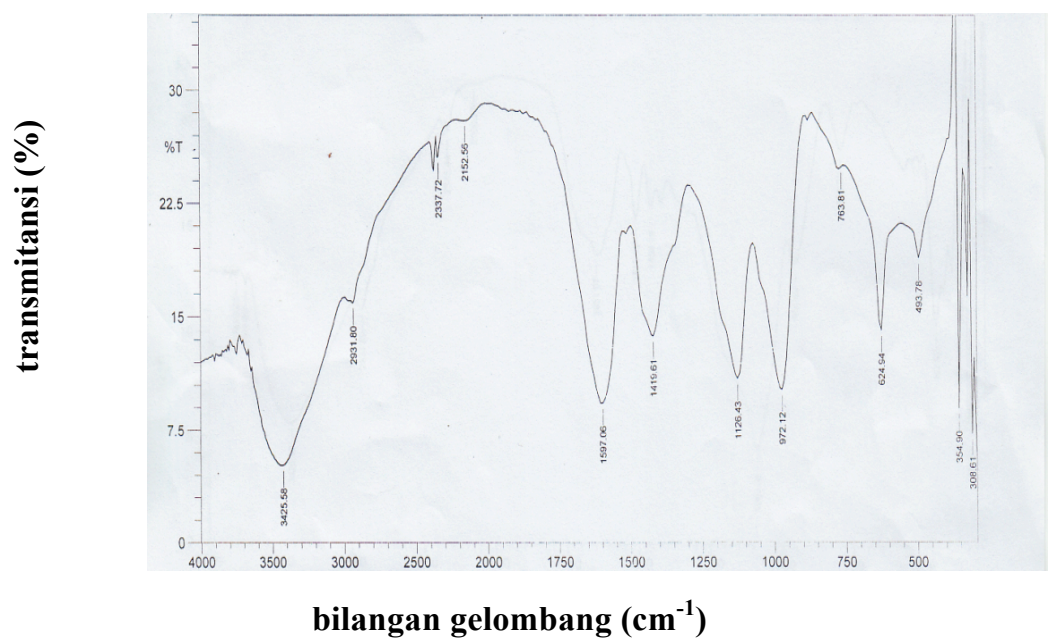

Gambar 7. Spektra FTIR Sodium Lignosulfonat (SLS) Komersial. 


\subsection{Uji Phase Behavior SLS Hasil Sintesis.}

Uji phase behavior dilakukan menggunakan minyak mentah (crude oil) dari Pengeboran Minyak Tanjung Kalimantan Selatan. Hasil uji menunjukkan, pada konsentrasi surfaktan 3000 dan 5000 ppm, terbentuk emulsi air dalam minyak (emulsi 2 fasa) atau disebut emulsi fasa atas. Jenis emulsi yang diharapkan dalam EOR/injeksi surfaktan adalah emulsi tiga fasa atau emulsi tengah atau paling tidak emulsi bawah (minyak dalam air). Dengan demikian surfaktan yang dihasilkan dalam penelitian ini belum dapat digunakan dalam pemungutan minyak bumi dengan metode injeksi surfaktan.

\section{Kesimpulan}

Berdasarkan hasil-hasil yang telah diuraikan sebelumnya, dapat diambil kesimpulan sebagai berikut: surfaktan Sodium Lignosulfonat dapat dibuat dari Jerami Padi melalui tahapan proses delignifikasi menggunakan $\mathrm{NaOH}$ dan isolasi lignin serta sulfonasi menggunakan natrium (sodium) bisulfit $\left(\mathrm{NaHSO}_{3}\right)$. Hasil yang relative baik diperoleh pada sulfonasi 2,5 g lignin hasil isolasi, persentase berat $\mathrm{NaHSO}_{3} 60 \%$ terhadap berat lignin, $\mathrm{pH}$ 7 , suhu $90-95^{\circ} \mathrm{C}$ selama 4 jam reaksi diperoleh $2,5509 \mathrm{~g}$ sodium lignosulfonat (SLS). Uji kelakuan fasa lignosulfonat menggunakan minyak mentah (crude oil) menunjukkan, pada konsentrasi surfaktan 3000 dan 5000 ppm, terbentuk emulsi air dalam minyak (emulsi 2 fasa); sehingga belum dapat digunakan sebagai surfaktan dalam pemungutan minyak bumi.

\section{Ucapan Terimakasih.}

Ucapan terima kasih disampaikan kepada LPPM UPN "Veteran" Yogyakarta yang telah menyediakan dana penelitian ini melalui hibah Nomor: B/60A/IV/2012/LPPM.

\section{Daftar Pustaka.}

Ani Suryani, Djulali M., Erliza Hambali dan Kosi Anwar, 2010, Proses optimasi suhu dan konsentrasi sodium bisulfit $\left(\mathrm{NaHSO}_{3}\right)$ pada pembuatan sodium lignosulfonat brbasis tandan kosong kelapa sawit (TKKS), J. Tek. Ind. Pert. Vol. 18(2),127-137.

Bailey, J.E, and D. F. Ollis, 1986, "Biochemical Engineering Fundamentals”, $2^{\text {nd }}$ Edition, McGrawHill, New. York

Berger, Paul, 2009, Surfactant Chemistry, ARC SP Workshop, oil chem. Technology Inc.

Dilling, Peter 1984, Low Electrolyte Sodium Lignosulfonate, Peter, US Patent 4590262

Fengel, D. dan G. Wegener, Penerjemah: Dr. Hardjono Sastrohamidjojo, 1985, "Kayu: Kimia Ultrastruktur Reaksi-reaksi”, Gadjah Mada University Press, Yogyakarta

Herri Susanto, 2009, Pengembangan Proses pemanfaatan Limbah Pertanian dan Perkebunan sebagai Sumber Energi dan bahan Kimia, Prosiding Seminar Nasional teknik Kimia 'Kejuangan', Jurusan Teknik Kimia, FTI,UPN "Veteran" Yogyakarta

Holmberg, Krister, 2001, Natural Surfactants, Current Opinion in Colloid and Interface Science, Elsevier, Sweden

Sri Wahyu Murni dan Siti Diyar Kholisoh, 2011, Produksi Enzim Selulase dari Trichoderma reesei secara Fermentasi dalam Media Kultur padat, Laporan Penelitian, LPPM UPN "Veteran” Yogyakarta

Sjostrom, Eero,1995, Kimia Kayu dasar-dasar dan Penggunaan, terjemahan: Dr. hardjono sastrohamidjojo, edisi kedua, Gadjah mada University Press, Yogyakarta

Supriadi Sadi, 1993, Penggunaan Minyak Sawit dan Inti sawit sebagai bahan baku surfaktan, Berita PPKS 1 (1) 